\title{
To Deliver Great Service you Need to Adopt A CSI Mindset
}

\author{
Julie Lyons-Wolfe* \\ The Handpiece Clinic, Canada
}

Submission: December 07, 2017; Published: February 16, 2017

*Corresponding author: Julie Lyons-Wolfe, President \& CEO, NextGen Handpiece Clinic Inc., Canada, Tel: 888-228-2521/613-216-2398;

Email: julielyonswolfe@gmail.com

\section{Opinion}

Have you ever experienced the phantom car noise?

You know what I am talking about. Those times in which a strange sound would emanate from under the hood, only to disappear the moment you drove it into the garage to be checked. Finally, and after countless trips back and forth to the shop, a light bulb would finally go off and your mechanic would discover the source of the noise, and repair the problem. In more cases than not, in turned out that the origin of the noise was totally unrelated to what the manuals had indicated.Most people would call this an A-HA moment. I personally prefer to call it a CSI moment.

\section{Why CSI?}

Because you are dealing with a mystery that requires a combination of expertise, gut instinct and an investigative perseverance that compels you to work on the problem until it is absolutely solved. Cue "Who Are You" music!

I also believe that these are the key attributes that distinguish good or passable service from great service. Specifically, how far beyond the in plain sight problems are you willing to go, to both identify and solve a client's service issue.

\section{A Case in Point}

Recently, we had received a hand piece unit requiring repair. Based on the description of what was wrong, we followed the normal procedures which included a parts replacement and thorough testing, before shipping it back to the client. Within a matter of hours after the repaired unit had been received, a call came in from the client indicating that the unit stopped working again.

I was more than a little surprised, given that it had been tested before we sent it back. The fact that it wasn't working was troubling, especially since it could cost the dentist chair time. Rather than rely on a courier, I personally drove out to the client's office to pick-up the unit. I then immediately returned to my office to place it in the care of my top technician.
Once the new replacement parts were installed, we tested, and then re-tested the unit to make doubly sure that there wasn't a problem. We also wanted to ensure that the replacement part was good, and that there were no other issues that we may had inadvertently missed.

Satisfied that the unit had been fixed, I drove it out to the dentist's office, confident that all would be well.

It wasn't. A short time later, we received another call from a patient, yet notably concerned dentist, indicating that the unit had failed once again. This is where my CSI mindset kicked into high gear.

Rather than simply repeating the standard process, my technician and I took a few moments to brainstorm. After all, we were 100 percent certain that there was nothing wrong with the parts we had used. If there were, then we would have received similar calls from other dentists experiencing the same issue. If it wasn't the parts my technician reasoned, then could it be something external to the unit itself? Hmm a possible clue.

As he thought about it further, it dawned on him that maybe there was a problem with o-rings. I called the dentist's office and discovered that the repaired units we had sent would stop working in one particular examination room. Off I went.

When I arrived at the dentist's office, I checked the o-rings to which the hand piece was attached. Sure enough, when the dentist touched it, the o-ring shattered into small pieces. What was happening is that when the dentist used the hand piece, small pieces of the now disintegrated o-ring would make their way into the unit. This in turn would jam up the turbine, causing the repeated malfunctions. Mystery solved, hand piece now working perfectly and most important of all . . . both the dentist and 1 learned something new.

Besides being glad that I am a fan of CSI, I am also happy that a long time ago, I had learned to think outside of the box in terms of problem solving. Had we simply stuck to the standard procedures 
and focused our time and energy on "fixing" the handpiece, we would have never discovered the real source of the problem, as well as the solution.
Roll closing credits, and be sure to tune in to next week's episode ;)

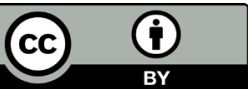

This work is licensed under Creative Commons Attribution 4.0 Licens

DOI: 10.19080/ADOH.2016.03.5555625
Your next submission with Juniper Publishers will reach you the below assets

- Quality Editorial service

- Swift Peer Review

- Reprints availability

- E-prints Service

- Manuscript Podcast for convenient understanding

- Global attainment for your research

- Manuscript accessibility in different formats ( Pdf, E-pub, Full Text, Audio)

- Unceasing customer service

Track the below URL for one-step submission https://juniperpublishers.com/online-submission.php 